\title{
Diversity and Distribution of Calvatia Species in India: A New Record from Central India
}

\author{
R.K. Verma, S.N. Mishra, Vimal Pandro* and A.K. Thakur
}

Forest Pathology Discipline, Forest Protection Division, Tropical Forest Research Institute, Jabalpur - 482 021, Madhya Pradesh, India

*Corresponding author

\section{A B S T R A C T}

\section{Keywords}

Calvatia, Calvatia pyriformis, Agaricaceae (Agaricales)

Article Info

Accepted:

18 August 2018

Available Online:

10 September 2018
An account of mushrooms belonging to Calvatia reported from different part of India is given. Total 16 species of were compiled from literature with their records of habitat, distribution and references. Jammu and Kashmir represents the maximum diversity of Calvatia and 5 species were reported followed by Himachal Pradesh (3 species), Assam, Madhya Pradesh and Uttarakhand (2 species each), West Bengal and Meghalaya (1 species each). One species Calvatia pyriformis was recorded for the first time from sal forest of central India.

\section{Introduction}

Calvatia belong to family Agaricaceae (Agaricales) is a mushroom forming fungi. The members of this family are commonly known as 'puff balls'.

There are 140 records of Calvatia species available on website, out of them 58 are valid names under the genus (http://www. indexfungorum.org). Genus Calvatia was erected by Swedish mycologist, Elias Magnus Fries as early as in 1849, which includes a single species, Calvatia craniiformis and it was originally described as Bovista craniiformis Schwein (Fries, 1849). Most species in the genus are edible when young, but some species for example, Calvatia fumosa, has a very pungent odour and should be avoided. Many wild species are collected and consumed around the world although species identified in the field and safely eaten vary widely from country to country. Calvatia gigantean (Batsch) Lloyd (giant puffball) and Calvatia utriformis (=Bovistella utriformis (Bull.) Demoulin \& Rebriev) were reported as edible (William and Arora, 2008).

Several studies have been conducted on taxonomic works on the genus (Lange, 1993; Zeller and Smith 1964; Morales and Kimbrough, 1978; Martín, 1997). Some workers classify Calvatia as a species complex (Kreisel, 1989, 1992). Studies on 
molecular phylogeny (Larsson and Jeppson, 2008; Bates et al., 2009) have not been decisive in the elucidation of the relationship of the monophyly of Calvatia. Recently many macro-fungi from central India have been reported including some edible, ecto mycorrhizal and saprophytic mushrooms (Verma et al., 2016a-c; Verma and Verma, 2017; Verma et al., 2017a-e; Verma et al., 2018a-b; Verma and Pandro2018a-b).

The present article reports distribution of 16 mushrooms belonging to genus Calvatia and reported from 8 states of India. Two species namely, Calvatia cyathiformis was recorded for the first time from central India (Madhya Pradesh) while and Calvatia pyriformis is new fungal record from India.

\section{Materials and Methods}

Specimens of Calvatia mushrooms were collected from Jabalpur and Chada, Dindori, Madhya Pradesh during June-July. Some parts of collected samples were preserved in $70 \%$ alcohol just after collection for microscopic study. The fruit bodies of fungi were dried under the sun or in the wooden box lighted with $100 \mathrm{~W}$ electric bulb. Microscopic slides were prepared by using stain, mountant, clearing and softening chemicals.

Slides were observed under advanced research microscope (Leica, Germany) using 5x, 10x, 20x, 40x objectives and 10x and 15x eyepieces. Observations under phase contrast and dark field were also made whenever required. Photomicrography was done with the help of a digital camera (make, Leica) attached to the advanced microscope.

Identification of fungi have been done with the help of published literature (Alfredo et al., 2014; Bisht et al., 2006; Chakraborty et al., 2012; Dorjey et al., 2016; Gogoi and Prakash, 2015; Gupta et al., 1974; Khare, 1976;
Kreisel, 1992; Syed Abrar et al., 2008; Thind and Thind, 1982; Zeller et al., 1964).

\section{Results and Discussion}

\section{Taxonomic description}

Calvatia cyathiformis (Bosc) Morgan (Figs. 1-8)

ELycoperdon cyathiforme Bosc Mag. Gesell.naturf. Freunde, Berlin 5: 87 (1811)

=Calvatia cyathiformis (Bosc) Morgan, $J$. Cincinnati Soc. Nat. Hist. 12(4): 168 (1890) subsp. cyathiformis

=Lycoperdon fragile Vittad., Mém. R. Accad. Sci. Torino, Ser. 2 5: 180 (1843)

=Utraria fragilis Quél., Compt. Rend. Assoc. Franç. Avancem. Sci. 14(2): 451 (1886)

=Calvatia fragilis (Quél.) Morgan, J. Cincinnati Soc. Nat. Hist. 12(4): 168 (1890)

=Calvatia cyathiformis subsp. fragilis (Quél.) Dring, Mycol. Pap. 98: 38 (1964)

=Calvatia cyathiformis f. fragilis (Quél.) A.H. Sm., Lloydia 27: 150 (1964)

Cyathiformis means flask shaped or like a flask. It is growing alone, scattered, gregariously in amongst grasses and pastures. Fruiting Body: $7-7.5 \mathrm{~cm}$ high and $6.5 \mathrm{~cm}$ wide when mature; ball-shaped when young, but soon developing a thick basal portion that is slightly more narrow than the upper portion, globose to turbinate or subpyriform, tapering abruptly into a large, well-developed, thick, stout rooting base, deeply wrinkled. Outer Surface: Tan to pale brown; the pigment breaking up into small, mosaic-like scales; eventually becoming very pale brown to grayish or nearly white, with a vague mosaic of sections punctuated by brownish dots; dry; the skin 1-2 mm thick. Interior: White and 
firm when young; soon becoming twochambered texturally, with the basal portion distinct from the upper portion; upper portion becoming yellowish and finally deep brownish purple as it matures and turns into spore dust; basal portion turning yellowish, then olive with age. Spore dust, purple. Basidiospores 3$6 \mu \mathrm{m}$ (including ornamentation); globose; covered with spines $0.5-1 \mu \mathrm{m}$ long; hyaline in $\mathrm{KOH}$; brownish in Melzer's reagent. Capillitial threads 2-5 $\mu \mathrm{m}$ wide; globose to subglobose, echinulate, walls about $0.5 \mu \mathrm{m}$ thick, flexuous or straight, sparsely branched, slightly; hyaline in $\mathrm{KOH}$; smooth or very minutely pitted; a little narrowed at septa.

Diagnostic characters include its habits of occurrence in grassy areas, a ball shaped when young, which on maturity develop a basal portion like inverted pear or a loaf of bread. The surface of mushroom can be fairly smooth and pale or, more commonly, brown and broken up into mosaic-like scales. It is similar species includes: Calvatia fragilis, $C$. gigantean and C. craniiformis.

\section{Collection examined}

On ground amongst herbaceous weeds and litter, TFRI campus, Jabalpur, Madhya Pradesh, 17/06/2013, Tropical Forest Research Institute TF-3434.

Calvatia pyriformis (Lév.) Kreisel (Figs. 918)

\section{इHippoperdon pyriforme Lév. 1846}

Fruit bodies roughly pear shaped, $7-9 \mathrm{~cm}$ tall and $6 \mathrm{~cm}$ broad, very short false stalk, wrinkled at base and lower side of the cap, outer wall is first white then pale yellowish to grayish brown, scurfy surface breaking up in to polygonal areas, inner wall papery grayish brown, the upper part breaking away to expose

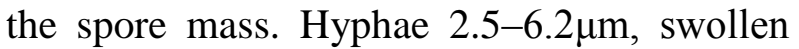
up to 5-15 $\mu \mathrm{m}$. Basidiospores globose to lemon shaped, centrally guttulate, olive - light brown, smooth, 3-5 x 2.5-3.5 $\mu \mathrm{m}$. Capillitial threads $2.5-10 \mu \mathrm{m}$ wide.

Fig.1-2 Calvatia cyathiformis (1) habit (2) a single fruit body in side view

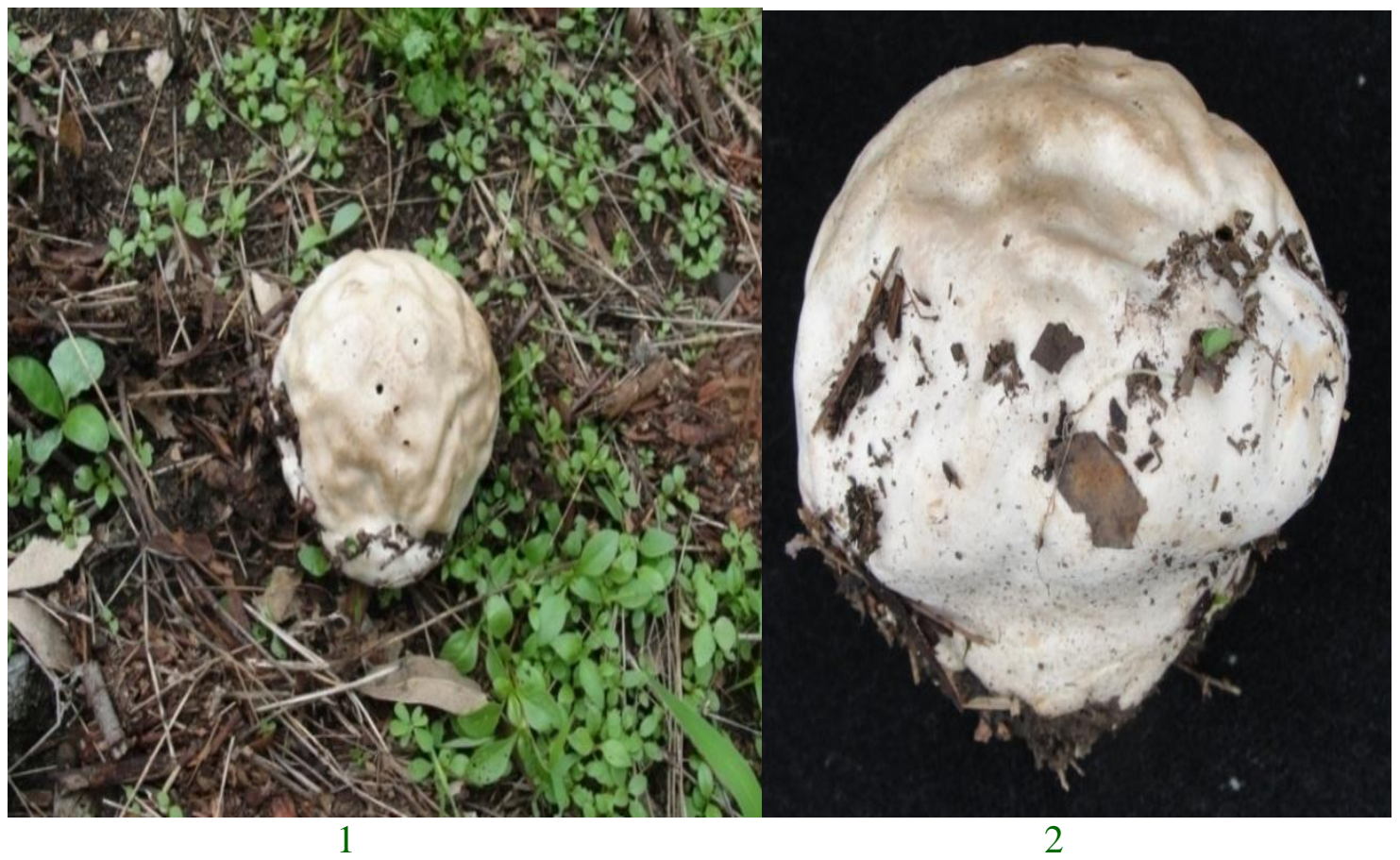


Fig.3-4 Calvatia cyathiformis (3) preserved specimen in 70\% alcohol and (4) cross section of preserved specimen

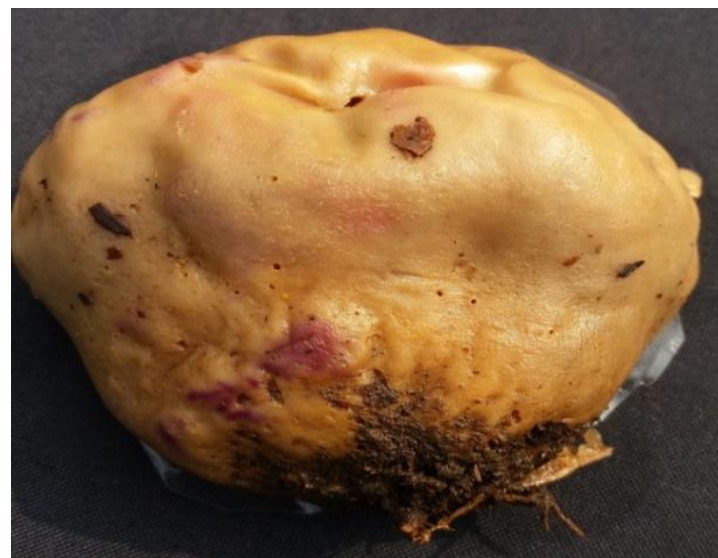

3

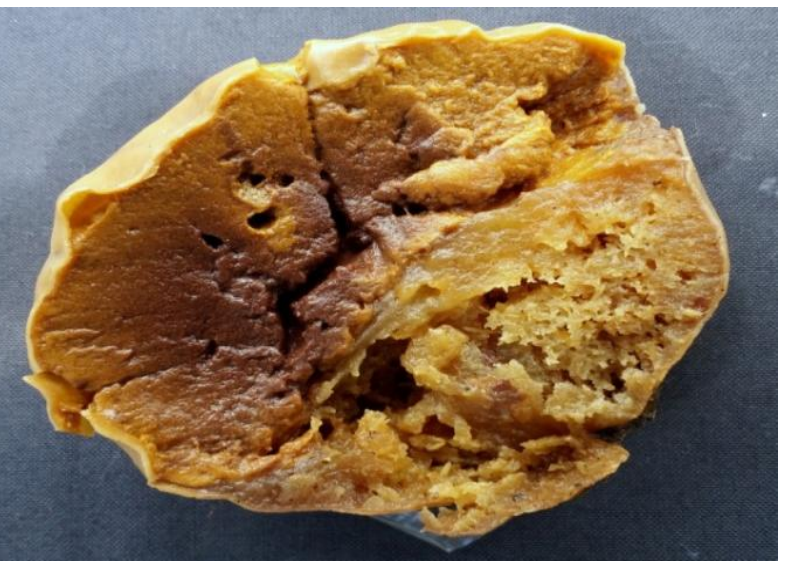

4

Fig.5-6 Calvatia cyathiformis (5) hyphae and basidiospores (6) enlargement of above showing a basidium and basidiospores

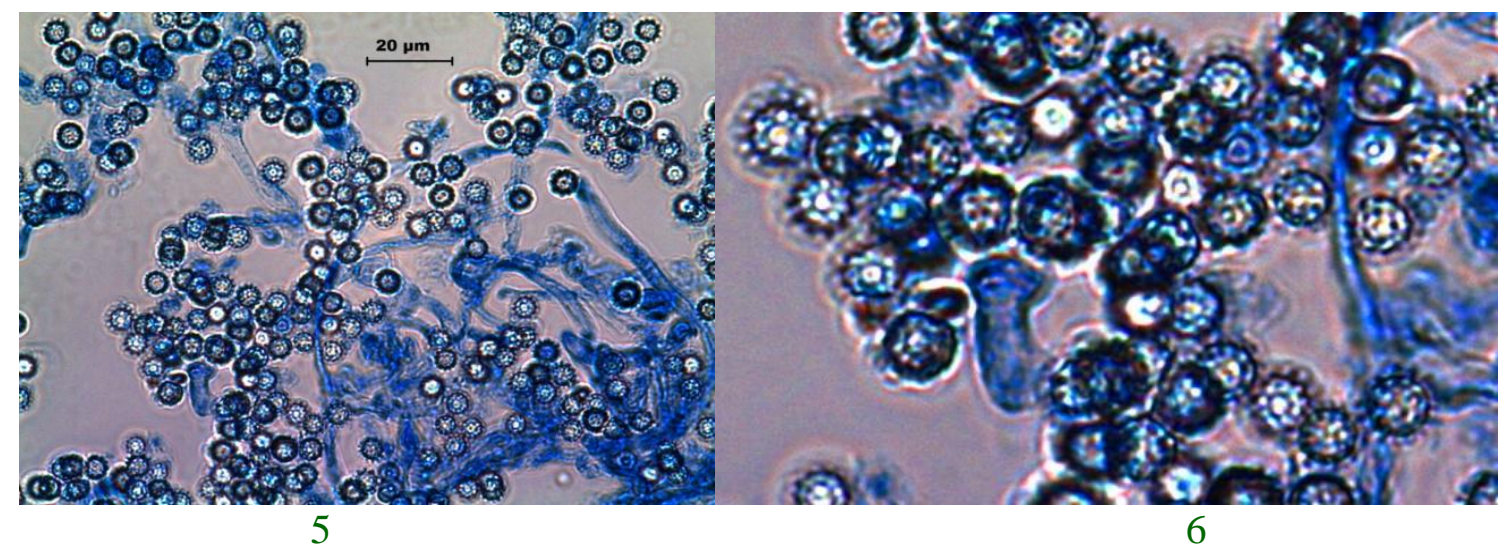

Fig.7-8 Calvatia cyathiformis (5) hyphae with pattern of capillitium characters and basidiospores (from preserved specimen)

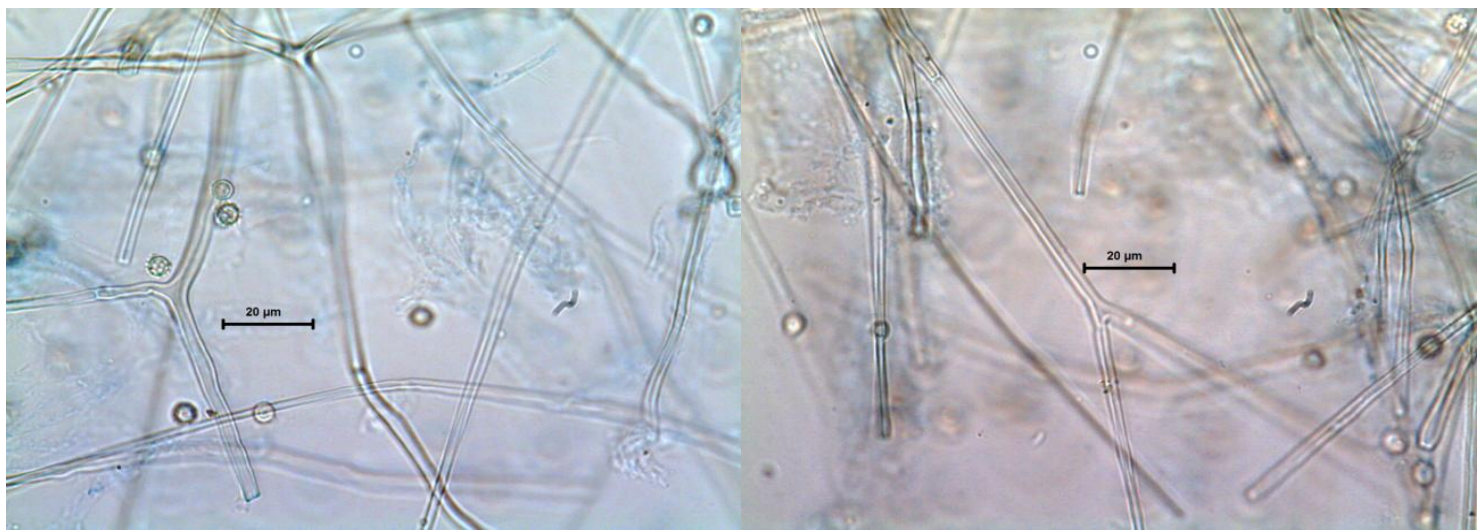


7

8

Fig.9-10 Calvatia pyriformis. 9 habit, 10 top view showing polygonal areas

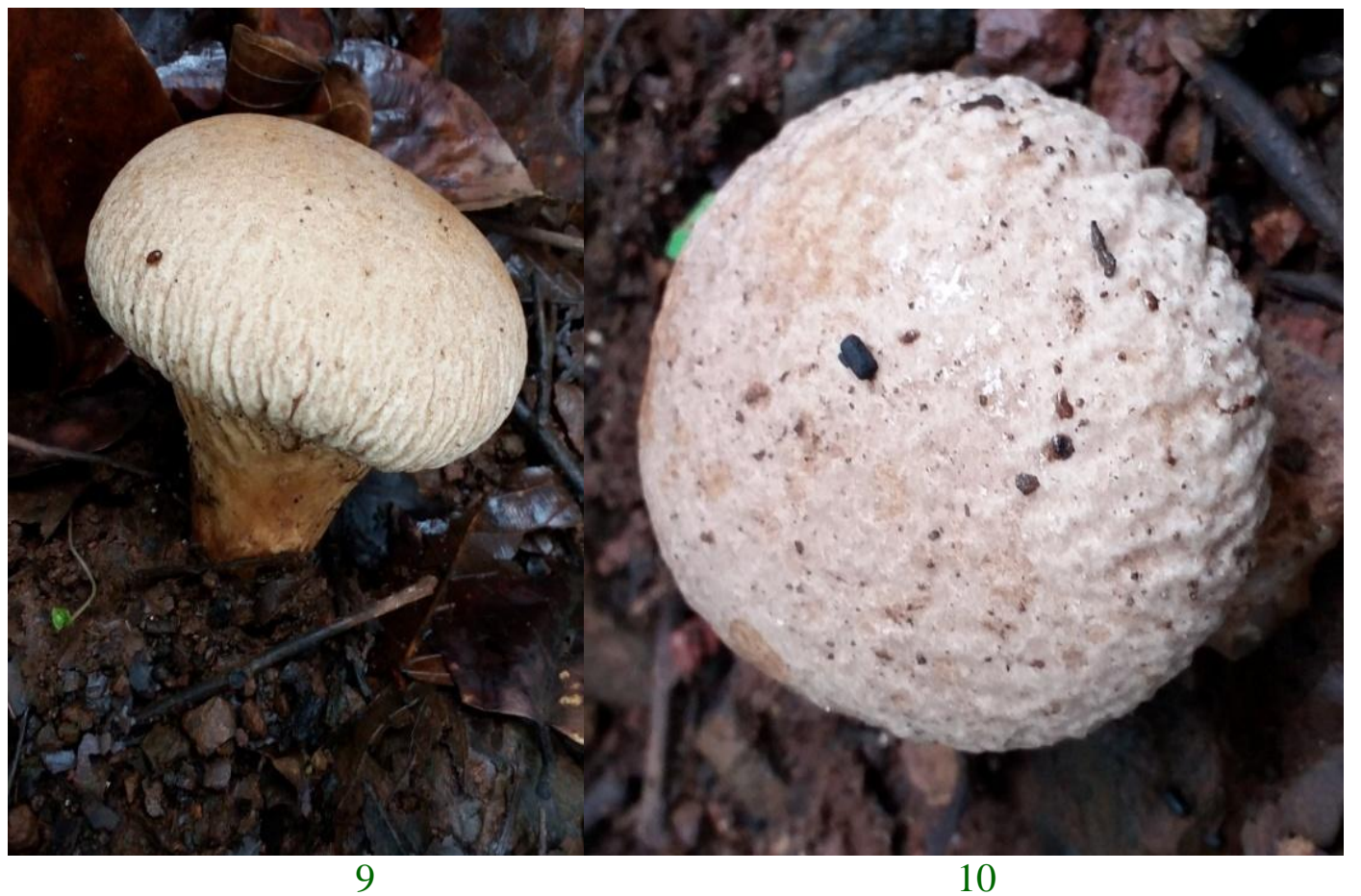

Fig.11-12 Calvatia pyriformis. 11 fruit body with stalk, 12 over mature fruit body showing disintegrating stalk

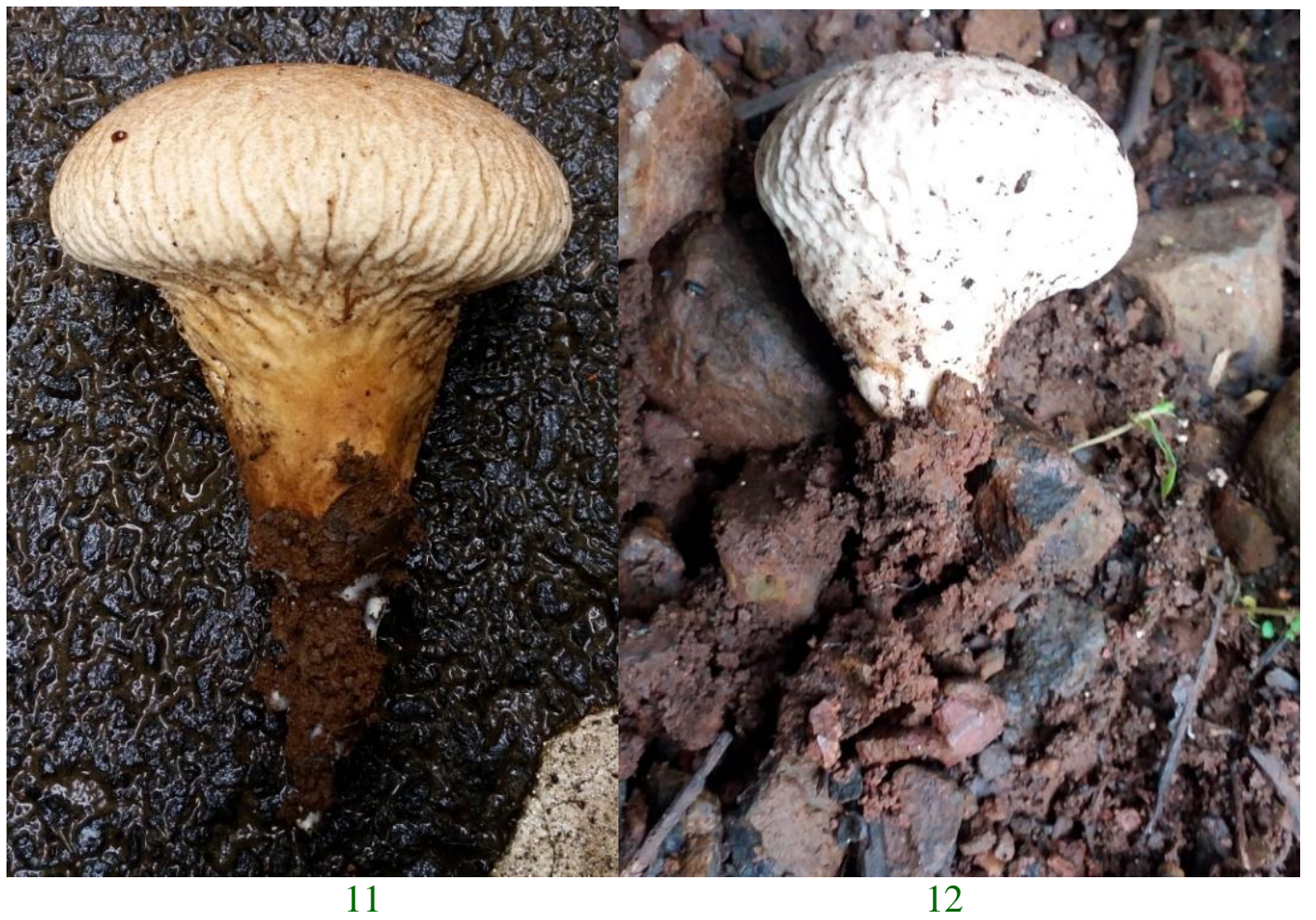


Fig.13-14 Calvatia pyriformis. 13 preserved fruit body with stalk, 14 different types of hyphae

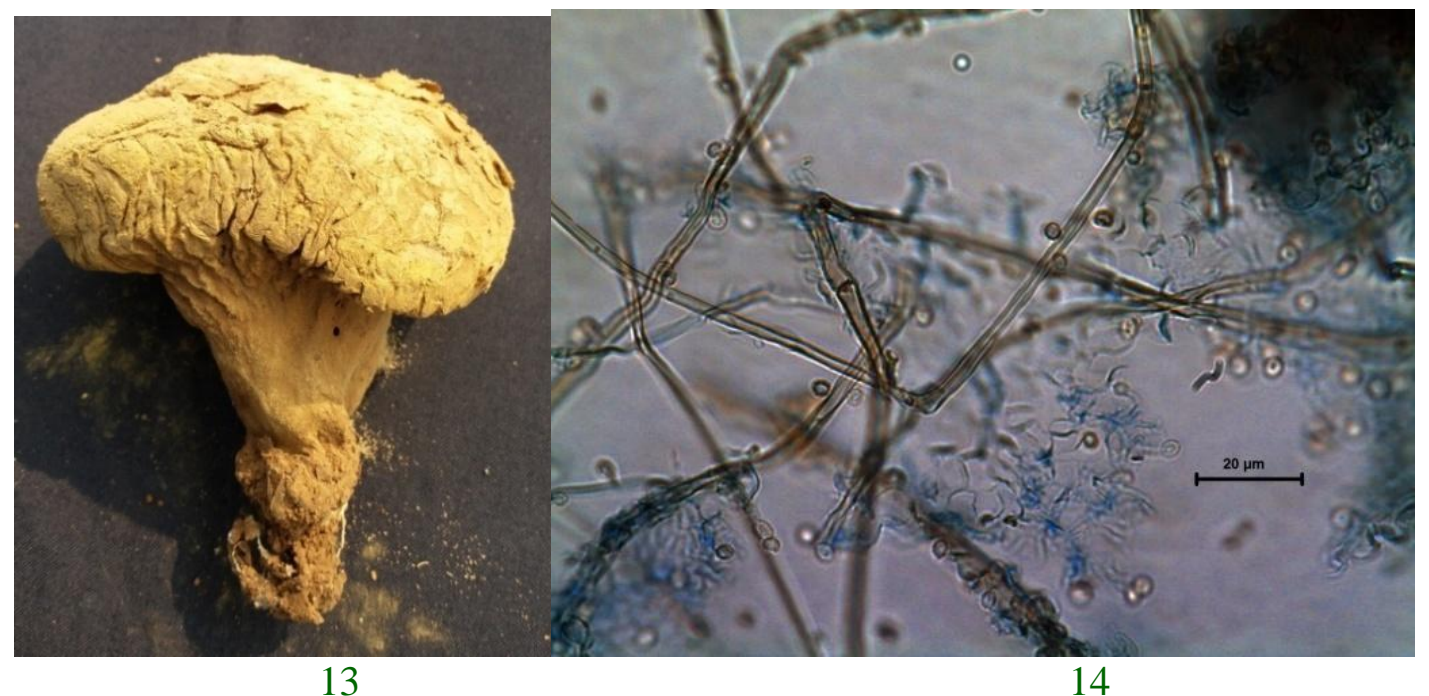

Fig.15-18 Calvatia pyriformis. 15-17 capillitium character, 18. Basidiospores

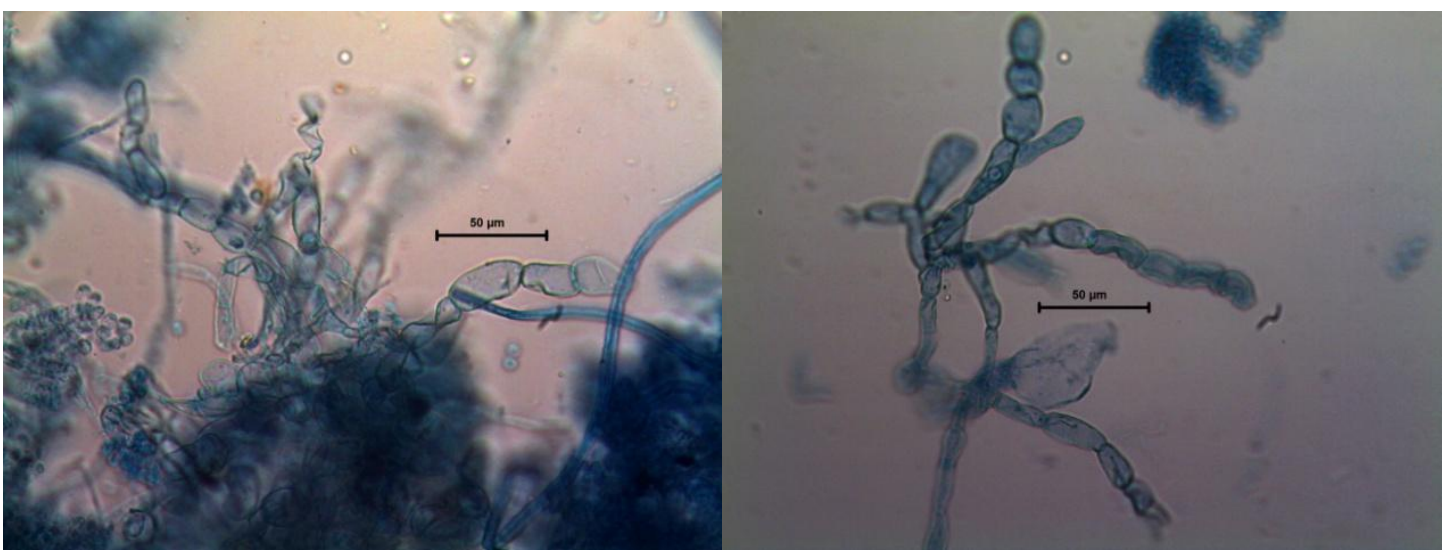

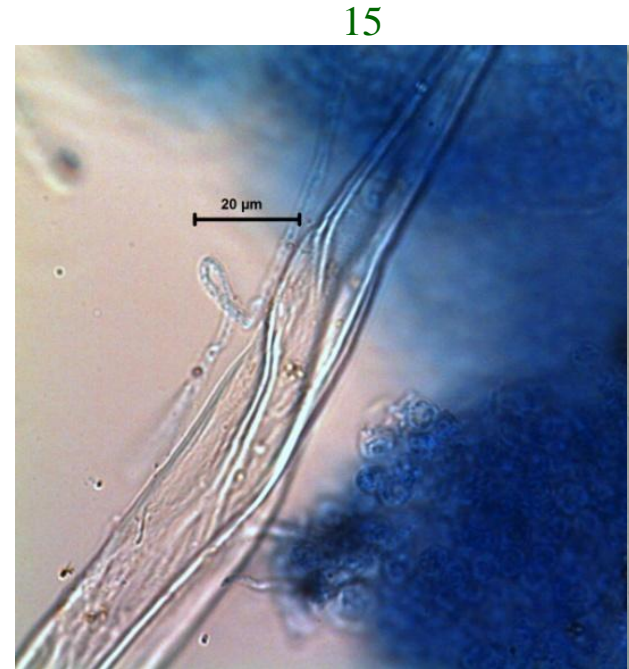

17

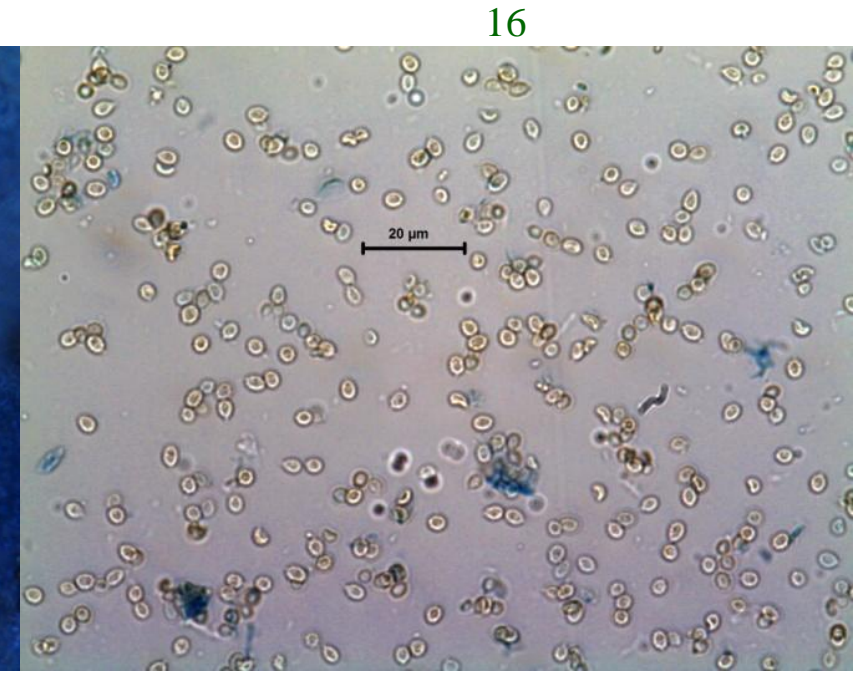

18 
Fig.19 Distribution of Calvatia species in different states shown on map of India with blackdots

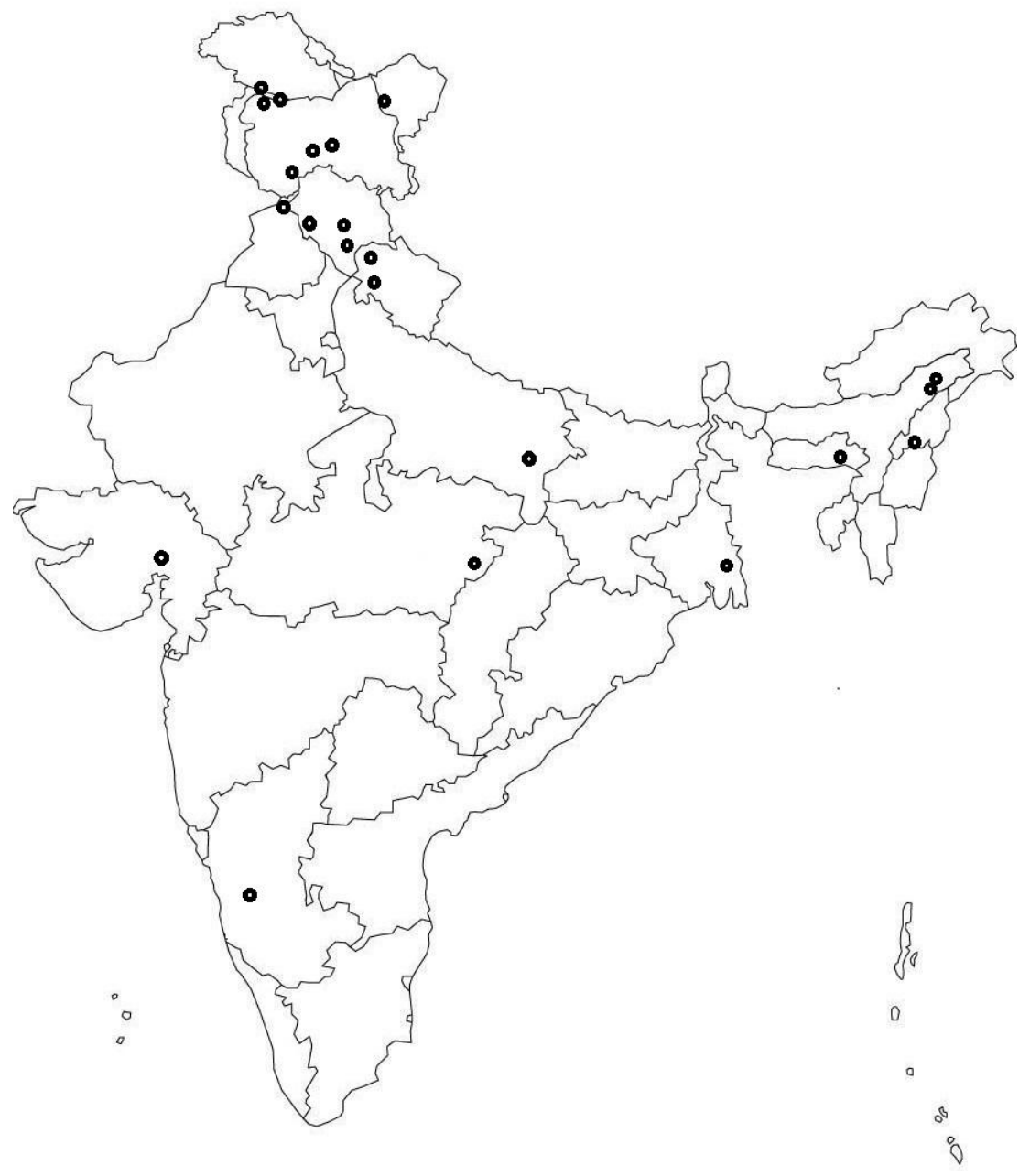

Table.1 Distribution of Calvatia mushroom in India

\begin{tabular}{|c|c|c|c|c|}
\hline S. No. & Name of fungus & Habit & Distribution & Reference \\
\hline 1. & Calvatia bovista (L.) Pers. & $\begin{array}{l}\text { Onhumicolous } \\
\text { soil, scattered } \\
\text { forests of Salix } \\
\text { alba and } \\
\text { Populusnigra }\end{array}$ & $\begin{array}{l}\text { Sumoor area, } \\
\text { Nubra, Leh, } \\
\text { Ladakh, Jammu and } \\
\text { Kashmir }\end{array}$ & $\begin{array}{l}\text { Dorjey et al., } \\
(2016)\end{array}$ \\
\hline 2. & $\begin{array}{l}\text { Calvatia caelata var. } \\
\text { caelata(Bull.) Morgan }\end{array}$ & Onground & $\begin{array}{l}\text { Babeh pass and } \\
\text { Bashahar state, HP }\end{array}$ & Ahmad (1941a) \\
\hline 3. & $\begin{array}{l}\text { Calvatia candida (Rostk.) } \\
\text { Hollós }\end{array}$ & From soil & Varanasi, UP & Khare (1976a) \\
\hline 4. & $\begin{array}{l}\text { Calvatia craniiformis } \\
\text { (Schwein.) Fr. ex De Toni } \\
\text { 三Bovista craniiformis Schwein. }\end{array}$ & $\begin{array}{l}\text { In open grounds } \\
\text { and meadows }\end{array}$ & $\begin{array}{l}\text { Shanthi Nagar, } \\
\text { Simoga, Karnataka }\end{array}$ & $\begin{array}{l}\text { Syed Abrar et } \\
\text { al., (2008) }\end{array}$ \\
\hline
\end{tabular}




\begin{tabular}{|c|c|c|c|c|}
\hline 5. & $\begin{array}{l}\text { Calvatia cyathiformis (Bosc) } \\
\text { Morgan }\end{array}$ & $\begin{array}{l}\text { From grassy soil; } \\
\text { growing in grassy, } \\
\text { moist and shady } \\
\text { place; it is edible } \\
\text { when young }\end{array}$ & $\begin{array}{l}\text { Ahmedabad, } \\
\text { Gujarat; } \\
\text { Jorhat, Assam; } \\
\text { Sankrail block, } \\
\text { Howrah, West } \\
\text { Bengal }\end{array}$ & $\begin{array}{l}\text { Rao (1964); } \\
\text { Khare } \\
\text { (1976a);Gogoi } \\
\text { and Prakash } \\
\text { (2015); } \\
\text { Chakraborty et } \\
\text { al., (2012); } \\
\text { Present article }\end{array}$ \\
\hline 6. & $\begin{array}{l}\text { Calvatia excipuliformis (Scop.) } \\
\text { Perdeck=Calvatia saccata } \\
\text { (Vahl) Morgan =Lycoperdon } \\
\text { saccatum Vahl }\end{array}$ & Onthe ground & $\begin{array}{l}\text { Mussoorie, } \\
\text { Uttarakhand; } \\
\text { Baramulla, Jammu } \\
\text { \& Kashmir }\end{array}$ & $\begin{array}{l}\text { Butler and Bisby } \\
\text { (1931) } \\
\text { Ahmad (1942) }\end{array}$ \\
\hline 7. & $\begin{array}{l}\text { Calvatia fenzlii(Reichardt) } \\
\text { Kawam. } \\
\text { 三LasiosphaerafenzliiReichardt }\end{array}$ & On manure & Unknown, India & $\begin{array}{l}\text { Butler and Bisby } \\
\text { (1931) }\end{array}$ \\
\hline 8. & Calvatia fragilis(Quél.) Morgan & $\begin{array}{l}\text { On humicolous } \\
\text { soil in coniferous } \\
\text { forest }\end{array}$ & Rajgadh, HP & $\begin{array}{l}\text { Gupta et al., } \\
\text { (1974) }\end{array}$ \\
\hline 9. & $\begin{array}{l}\text { Calvatia gardneri(Berk.) Lloyd } \\
\equiv \text { LycoperdongardneriBerk. }\end{array}$ & On ground & $\begin{array}{l}\text { Khasi Hills, } \\
\text { Meghalaya }\end{array}$ & $\begin{array}{l}\text { Lloyad (1904- } \\
\text { 1919) }\end{array}$ \\
\hline 10. & $\begin{array}{l}\text { Calvatia gigantea }(\text { Batsch }) \\
\text { Lloyd } \equiv \text { Lycoperdon } \\
\text { giganteumBatsch }\end{array}$ & On ground & $\begin{array}{l}\text { Sonamarg, Kashmir } \\
\text { Kohima, Nagaland }\end{array}$ & $\begin{array}{l}\text { Ahmad (1941a) } \\
\text { Bhaben et al., } \\
\text { (2011) }\end{array}$ \\
\hline 11. & $\begin{array}{l}\text { Calvatia lilacina(Mont. \& } \\
\text { Berk.) Henn. =Bovistalilacina } \\
\text { Mont. \&Berk., }\end{array}$ & Onsandy soil & Gurdaspur, Punjab & Ahmad (1941b) \\
\hline 12. & $\begin{array}{l}\text { Calvatia longicauda (Henn.) } \\
\text { Lloyd }\end{array}$ & Onsoil & $\begin{array}{l}\text { FRI campus, } \\
\text { Dehradun, } \\
\text { Uttarakhand }\end{array}$ & $\begin{array}{l}\text { Bisht et al., } \\
\text { (2006) }\end{array}$ \\
\hline 13. & $\begin{array}{l}\text { Calvatia lycoperdoides } \\
\text { A.H. Sm. }\end{array}$ & $\begin{array}{l}\text { Growingsolitary- } \\
\text { gregarious in } \\
\text { coniferous forests, }\end{array}$ & $\begin{array}{l}\text { Bhadarwash, } \\
\text { Athkhar, Jammu \& } \\
\text { Kashmir }\end{array}$ & $\begin{array}{l}\text { Kumar and } \\
\text { Sharma (2011a) }\end{array}$ \\
\hline 14. & $\begin{array}{l}\text { Calvatia pachyderma }(\text { Peck }) \\
\text { Morgan =Lycoperdon } \\
\text { pachydermumPeck }\end{array}$ & $\begin{array}{l}\text { Onhumicolous soil } \\
\text { in coniferous } \\
\text { forest }\end{array}$ & Khadrala, HP & $\begin{array}{l}\text { Gupta et al., } \\
\text { (1974) }\end{array}$ \\
\hline 15. & $\begin{array}{l}\text { Calvatia pyriformis (Lév.) } \\
\text { Kreisel }\end{array}$ & $\begin{array}{l}\text { On ground in sal } \\
\text { forest }\end{array}$ & $\begin{array}{l}\text { Chada, Dindori, } \\
\text { Madhya Pradesh }\end{array}$ & Present article \\
\hline 16. & $\begin{array}{l}\text { Calvatia rubroflava(Cragin) } \\
\text { Lloyd }\end{array}$ & $\begin{array}{l}\text { growing on } \\
\text { humicolous } \\
\text { scattered mixed } \\
\text { forests of conifers } \\
\text { and broad leaved } \\
\text { trees }\end{array}$ & $\begin{array}{l}\text { Kishtwar, Padder, } \\
\text { Jamuu \& Kashmir; } \\
\text { from Jorhat, Assam }\end{array}$ & $\begin{array}{l}\text { Kumar and } \\
\text { Sharma (2011a); } \\
\text { Gogoi and Vipin } \\
\text { (2015) }\end{array}$ \\
\hline
\end{tabular}




\section{Collection examined}

On ground in sal forest, Chada, Dindori, Madhya Pradesh, 24/07/2017, Tropical Forest Research Institute TF 3989.

The 16 mushrooms belonging to genus Calvatia were recorded from 8 different states of India. Out of them, five species were recorded from Jammu and Kashmir these include: $C$. bovista, $C$. gigantea, $C$. lycoperdoides, $C$. rubroflava and $C$. saccata (Ahmad, 1942; Dorjey et al., 2016; Kumar and Sharma, 2011a). Three species ( $C$. caelata var. caelata, $C$. pachyderma and $C$. fragilis), were recorded from Himachal Pradesh (Ahmad, 1941a; Gupta et al., 1974). Two species each were reported from Assam and Uttarakhand these are: $C$. cyathiformis, $C$. rubroflava, $C$. excipuliformis and $C$. longicauda (Gogoi and Vipin, 2015; Kumar and Sharma, 2011a; Butler and Bisby, 1931; Bisht et al., 2006). One species each of Calvatiawas recorded from Punjab, Meghalaya and UP these are $C$. lilacina, $C$. candida, C. gardneri, respectively (Ahmad, 1941b; Lloyad, 1904-1919; Khare, 1976a)while one species, $C$. fenzliiwas reported from unknown place of India (Butler and Bisby, 1931) (Table 1).

Calvatia cyathiformis is distributed mostly in prairie or grasslands in North America, Illinois, Québec and Australia. It is edible and steroids were also isolated from this mushroom. While the second species described above, C. pyriformis is distributed in tropical forests of Africa, Mauritius, Sri Lanka, Java, Japan, Indonesia, Mexico, Panama, Costa Rica, Ecuador, Peru and Bolivia.

Species of Calvatia were recorded from different types of soils and substrates including, humicolous soil, grassy soil, sandy soil, on manure, on soils of moist and shady places. The main habitat of this mushroom reported in literature includes forests of Salix alba, Populus nigra, broad leaved forests, coniferous forest and sal forest.

Some of Calvatia species were reported to be edible as long as the inside is pure white and it should be consumed within 24 hours of harvest. The fruit bodies of Calvatia cyathiformis are edible when young (Chakraborty et al., 2012). An account on ethno-myco-medicines from central India was reported (Rai et al., 1993). Two steroids including, Calvasterols A $(14 \alpha-$ hydroxyergosta-4, 7, 9, 22-tetraen-3, 6-dione) and B (9 $\alpha, 14 \alpha$-dihydroxyergosta-4, 7, 22trien-3, 6-dione) and a novel dimeric steroid and calvasterone were detected from the fungus, Calvatia cyathiformis (Kawahara et al., 1993; 1994, 1995). Calvacin a new antitumor agent was also reported (Roland et al., 1960). Ethnomycology and biotechnological potential species of genus Calvatia, namely C. cyathiformis, C. craniiformis, $C$. excipuliformis, $C$. gigantean and $C$. utriformisis reviewed and reported that these are sources of food and traditional medicine (Coetzee and van Wyk, 2009). Indigenous knowledge of ethnic tribes for utilization of wild mushrooms including $C$. gigantea as food and medicine in Similipal biosphere reserve, Odisha was studied by Sachan et al., (2013). This species was also tested for medicinal compounds and was determined that extracts of this species contains calvacin which is a strong tumor-retarding substance present in immature basidiocarp (Roland et al., 1960).

Mushrooms of genus Calvatia were distributed in 8 states of India (Assam, Himachal Pradesh, Jammu \& Kashmir, Madhya Pradesh, Meghalaya, Uttarakhand and West Bengal). Jammu \& Kashmir 
represents the maximum species diversity. Two species namely, Calvatia cyathiformis and Calvatia pyriformis were recorded for the first time from central India (Madhya Pradesh).

\section{Acknowledgements}

The authors are thankful to Dr. G. Rajeshwar Rao, Director, Tropical Forest Research Institute, Jabalpur for providing the research facilities. The work presented was conducted under project ID No. 224/TFRI/2016/Patho1(22) funded by India Council of Forest Research \& Education (ICFRE), Dehradun.

\section{References}

Alfredo DS, Rodrigues ACM and Baseia IG (2014). Calvatia nodulata, a new gasteroid fungus from Brazilian semiarid region. Journal of Mycology, Article ID 697602, 7 pages

Bates ST, Roberson RW, and Desjardin DE (2009).Arizona gasteroid fungi I: Lycoperdaceae (Agaricales, Basidiomycota). Fungal Diversity37: 153-207.

Bhaben T, Lisha G and Chandra SG (2011). Wild edible fungal resources used by ethnic tribes of Nagaland, India. Indian Journal of Traditional Knowledge 10(3): 512-515.

Bisht Dipika, Sharma JR, Kreisel H, Das K (2006). A new species and a new record of Lycoperdaceae from India. Mycotaxon95: 91-96.

Chakraborty N, Pradhan P, Dutta AK, Acharya K (2012). Calvatia cyathiformis: new record from West Bengal. Sci. \& Cult.78 (3-4) 161-163.

Coetzee JC, van Wyk AE (2009). The genus Calvatia ('Gasteromycetes', Lycoperdaceae): a review of its ethnomycology and biotechnological potential. African Journal of Biotechnology 8(22): 6007-6015.

Dorjey K, Kumar S, Sharma YP (2016). Desert puffballs from LadakhtransHimalaya (J\&K), India - the genus Bovistaand Calvatia. Indian Phytopath. 69 (1): 87-92.

Fries EM (1849). Summa vegetabilium Scandinaviae (in Latin). 2. Uppsala, Sweden: Typographia Academica. p. 442.

Gogoi G, Prakash Vipin (2015). Diversity of Gasteroid Fungi (Basidiomycota) in Hollongapar Gibbon Wildlife Sanctuary, Jorhat, Assam, India. Current Research in Environmental \& Applied Mycology 5(3): 202-212,

Gupta KK, Agarwal RK, Kumar S, Seth PK. (1974). Gasteromycetes of Himachal Pradesh. Indian Phytopath. 27(1): 4548.

http://www.indexfungorum.org/names/Names .asp (page visited on 13/06/2018)

Kawahara N, Sekita S, Satake M (1993). A novel dimeric steroid, calvasterone from the fungus Calvatia cyathiformis. Chem. Pharm. Bull. 41: 1318-1320.

Kawahara N, Sekita S, Satake M (1994). Steroids from Calvatia cyathiformis. Phytochem. 37: 213-215.

Kawahara N, Sekita S, Satake M (1995). Two steroids from Calvatia cyathiformis. Phytochemistry 38: 947-950.

Khare KB (1976). Some Gasteromycetes from Uttar Pradesh. Indian Phytopath. 29: 34-38.

Kreisel H. (1989). Studies in the Calvatia complex (Basidiomycetes). Nova Hedwigia48: 281-296.

Kreisel H. (1992). An emendation and preliminary survey of the genus Calvatia (Gasteromycetidae). Persoonia, 14: 431-439.

Kreisel, H. (1992). An emendation and preliminary survey of the genus 
Calvatia (Gasteromycetidae). Persoonia 14(4): 431-439.

LangeM. (1993).Classifications in the Calvatia group. Blyttya 51:141-144.

Larsson E. and Jeppson M. (2008). Phylogenetic relationships among species and genera of Lycoperdaceae based on ITS and LSU sequence data from North European taxa. Mycological Research 112(1): 4-22.

Martín M.P. (1997). Exoperidium and spores of Calvatiautriformis.Mycotaxon61: 381-387.

Morales M.I. and Kimbrough J.W. (1978).The lycoperdaceae of North Central Florida I. The genera Calvatia and Disciseda. Revista de Biología Tropical11: 227-236.

Morgan, A.P. 1891. North American fungi. The Gasteromycetes: 3. Journal of the Cincinnati Society of Natural History. 12:163-172

Rai BK, Ayachi SS, Rai A (1993). A note on ethno-myco-medicines from Central India. Mycologist, 4: 192-193.

Roland JF, Chmielewicz ZF, Weiner BA, Gross AM et al., (1960). Calvacin: A New Anti-Tumor Agent. Science 132: 1897

Sachan SKS, Patra JK and Thatoi HN (2013). Indigenous knowledge of ethnic tribes for utilization of wild mushrooms as food and medicine in similipal biosphere reserve, Odisha, India. Journal of Agricultural Technology 9(2):403-416.

Syed Abrar, Swapna S, Krishnappa M (2008). Bovistaaestivalis and Calvatia craniiformis - new records to India. Journal of Mycology and Plant Pathology 38 (3): 504-506.

Thind KS, Thind IPS (1982). The Gasteromycetes of the Himalayas II. Jour. Ind. Bot. Soc. 61:19-32.

Verma R.K., Pandro Vimal, Asati H.L. (2018a). Diversity of macro-fungi in
Central India-XII: Leucoagaricus rubrotinctus. Van Sangyan 5(4): 1-10.

Verma RK, Asaiya AJK, Choubey Chitra, Pandro Vimal (2017a). Diversity of Macro-fungi in central India-IX: Laetiporus sulphureus. Van Sangyan 4(11): 1-6.

Verma RK, Pandro V (2018a). Diversity and distribution of amanitaceous mushrooms in India, two new reports from sal forest of central India. Indian Journal of Tropical Biodiversity 26(1): 42-54.

Verma RK, Pandro V (2018b). Distribution of Boleteceous mushrooms in India, some new records from Sal forest of central India. International Journal of Current Microbiology and Applied Science 7(6): 1694-1713.

Verma RK, Pandro Vimal, Verma Poonam (2017b). Diversity of macro-fungi in central India - VII. Polyporus grammocephalus. Van Sangyan 4(9): 18.

Verma RK, Rajput PS, PandroVimal (2017c). Diversity of Macro-fungi in central India-VIII: Astraeus hygrometricus, an ectomycorrhizal and neutraceutical mushroom from sal forests. Van Sangyan 4(10): 18-29.

Verma RK, Thakur AK, Pandro Vimal (2017d). Diversity of Macro-fungi in central India-X: edible mushrooms Macrocybe crassa and Macrocybe lobayensis. Van Sangyan 4(12): 39-49.

Verma RK, Tiwari CK, Parihar J, Shailendra Kumar (2016a). Diversity of Amylosporus campbelli in central India. Van Sangyan 3(11): 20-23.

Verma RK, Tiwari CK, Parihar J, Shailendra Kumar (2016c). Diversity of macrofungi in central India -II. Clarkeindatrachodes. Van Sangyan 3(12): 17-20.

Verma RK, Tiwari CK, Parihar J, Verma P (2017e). Diversity of macro-fungi in 
central India-V. Tremella fusiformis. Van Sangyan 4(3): 46-50.

Verma RK, Verma P (2017). Diversity of macro-fungi in central India -IV. Auricularia auricular-judae, a neutracetical jelly mushroom. Van Sangyan 4(2): 23-31.

Verma RK, Verma Poonam, Mishra Y (2016b). Headless stinkhorn fungi (Mutinus spp.) with special reference to Indian species. Indian $\mathrm{J}$ Trop Biodiv 24(1): 75-80.
William Rubel and Arora David (2008).A study of cultural bias in field guide determinations of mushroom edibility using the iconic mushroom, Amanita muscaria, as an example. Economic Botany 62(3): 223-243.

Zeller S.M. and Smith A.H. (1964). The genus Calvatia in North America. Lloydia 27(3): 148-186.

\section{How to cite this article:}

Verma, R.K., S.N. Mishra, Vimal Pandro and Thakur, A.K. 2018. Diversity and Distribution of Calvatia Species in India: A New Record from Central India. Int.J.Curr.Microbiol.App.Sci. 7(09): 2540-2551. doi: https://doi.org/10.20546/ijcmas.2018.709.316 